\title{
Neonatal herpes encephalitis: a rare cause of neonatal refractory seizures and challenge for neonatologist
}

\begin{abstract}
Neonatal herpes simplex virus (HSV) infections are one of the most severe of all infections acquired during the perinatal period. HSV 2 accounts for majority of the neonatal HSV infections with intrapartum route being the most common pathway for transmission to the newborn. Clinical presentation can vary from skin involvement to disseminated infection, which when present has high mortality and neurological morbidity. Here we report a newborn with refractory seizures, acute infarct on MRI and was diagnosed as a case of HSV encephalitis. Baby was treated with antiviral drug and was discharged successfully and now in follow up.
\end{abstract}

Keywords: HSV encephalitis, refractory neonatal seizure, SEM disease (skin eye and mucosal), CNS disease and disseminated disease
Special Issue - 2015

\section{Deepak Sharma, Srinivas Murki, Oleti Tejo \\ Pratap}

Department of Neonatology, Fernandez Hospital, India

\author{
Correspondence: Deepak Sharma, Neonatology, Fernandez \\ Hospital, Opposite Old MLA quarters, Hyderguda, Pin 500029, \\ Hyderabad, India, Tel 9849590876 ,
}

Email dr.deepak.rohtak@gmail.com

Received: May 07, 20I5 | Published: May 25, 2015
Abbreviations: HSV, herpes simplex virus; SEM, skin eye and mucosal; CSF, cerebrospinal fluid, EEG, electroencephalography; MRI, magnetic resonance imaging; CNS, central nervous system; DIC, disseminated intravascular coagulation

\section{Introduction}

Neonatal HSV encephalitis is a very rare and severe infection which requires a high degree of clinical suspicion, as in many a history of exposure is absent and delay in therapy would be life threatening. HSV infection has varied manifestation in the newborn. Treating neonatologists always rule out the common causes of neonatal seizures but this rare etiology may present with refractory seizures in some and in them an early diagnosis would result in optimal outcomes. This case will guide the clinicians in having an index of suspicion for Herpes encephalitis in newborns presenting with refractory seizures.

\section{Case report}

A 29 days female old neonate born to a couple with nonconsanguineous marriage, was admitted with us with complains of abnormal body movements in form of jerky movements of right upper and lower limbs, lasting for few seconds for the last 2 days. Along with abnormal movements the mother also noted the infant was irritable and had excessive crying episodes. However was feeding well from the breast. There was no history of any fever, rash or altered feeding behavior. At birth, the baby weight 2800 grams and had a normal perinatal course. The mother was primigravida mother with normal supervised antenatal period. The blood group of mother was $B$ positive and all serological tests were non-reactive. The antenatal scans were normal. It was on exclusive breast feeds right from birth. There was a history of paternal grandmother having seizures since her childhood. On admission, the newborn was stuporous, had decreased activity, head lag, generalized hypotonia with upper limbs being more hypotonic. There was no focal deficit. Pupils were of normal size and reacting to light. Head circumference was $36 \mathrm{~cm}$. Vitals were normal. Rest of the systemic exam was non-contributory.

Blood sugar was $103 \mathrm{mg} / \mathrm{dl}$, serum calcium $9.2 \mathrm{mg} / \mathrm{dl}$, serum magnesium $1.5 \mathrm{mg} / \mathrm{dl}$, sodium $136 \mathrm{meq} / \mathrm{dl}$, Potassium $5.9 \mathrm{meq} / \mathrm{dl}$. Screen for sepsis was negative including normal WBC counts $8300 /$ $\mathrm{mm} 3, \mathrm{C}$-reactive protein of $0.1 \mathrm{mg} / \mathrm{dl}$. Blood cultures were sterile. EEG done at 24 hours of admission showed normal background activity and focal discharges. CSF exam revealed $11 \mathrm{cell} / \mathrm{s} / \mathrm{mm} 3$ with all being lymphocytes, sugar of $40 \mathrm{mg} / \mathrm{dl}$ (corresponding blood sugar $71 \mathrm{mg} / \mathrm{dl}$ ), and protein of $69 \mathrm{mg} / \mathrm{dl}$ with no growth on culture. Seizures were controlled with Phenobarbital (loading dose of $20 \mathrm{mg}$ / $\mathrm{kg}$ with maintenance dose of $5 \mathrm{mg} / \mathrm{kg} /$ day). By day 3 the newborn was seizure free and was started on breast feed. On day 4 the infant again had refractory focal clonic seizures that got controlled with second loading dose of phenobarbitone $(10 \mathrm{mg} / \mathrm{kg}$ ) and phenytoin (loading with $20 \mathrm{mg} / \mathrm{kg}$ with maintenance dose of $5 \mathrm{mg} / \mathrm{kg}$ /day). EEG when repeated showed background rhythm of symmetrical slow wave activity with intermittent generalized spike wave discharge suggestive of generalized seizure disorder. MRI brain showed focal area of restricted diffusion in right thalamus, bilateral frontal and parietal region extending into perirolandic region suggesting of acute infarct (Figure 1).

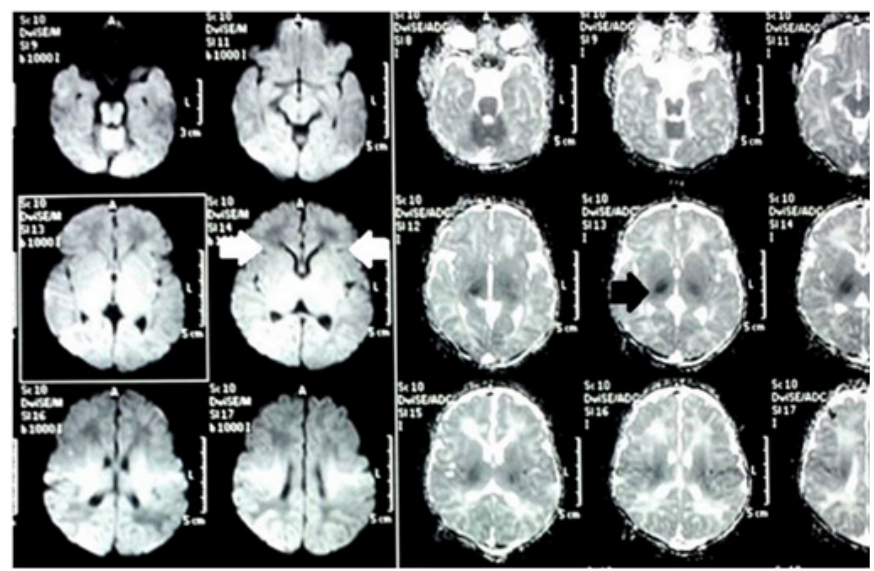

Figure I MRI brain showed focal area of restricted diffusion in right thalamus, bilateral frontal and parietal region extending into perirolandic region suggesting of acute infarct

A differential of dengue encephalitis, Japanese encephalitis, Herpes encephalitis and congenital malaria were considered. Smear for malaria was negative. Infant was started on empirical acyclovir. Repeat CSF PCR was positive for HSV type 2. Infant was treated with 
21 days of acyclovir. Antiepileptics were gradually tapered and the newborn was discharged on maintenance doses of phenytoin $(5 \mathrm{mg} /$ $\mathrm{kg} /$ day). CSF repeated at the end of therapy was normal. Neurological examination at follow did not reveal any focal deficit. The infant is on long term followed up.

\section{Discussion}

Herpes simplex viruses (HSV-1 and HSV-2) are large, enveloped virions with a double stranded DNA core and belong to alpha herpes virus subfamily of Herpesviridae family. Humans are the only known natural reservoir of HSV. Neonatal herpes simplex virus (HSV) infections are one of the most severe of all infections acquired by the neonate. It is an uncommon occurrence with an estimated to be between 1 in 3000 to 1 in 20000 deliveries. ${ }^{1}$ These infections are usually because of fetal contact with infected maternal secretions; therefore, the early identification of infected babies and prompt intervention with antiviral drugs leads to an improved therapeutic outcome. ${ }^{2}$ The prevalence of HSV infection in 0- to 28-day-old infants is estimated to be about $0.2 \%$ and HSV infection is thought to account for illness in $0.3 \%$ to $0.9 \%$ of febrile neonates. ${ }^{3,4}$ As HSV-2 resides in the genital tract, neonatal herpes simplex virus (HSV) infections are most commonly acquired via ascending intrauterine infection, exposure to an infected maternal birth canal, or postnatal infection. ${ }^{5}$ The risk of neonatal infection with HSV is significantly higher with first-episode primary and first-episode non primary maternal infections when compared with recurrent genital infections. HSV 2 is the most common cause of neonatal HSV encephalitis with incidence of around 75-86\%. ${ }^{6}$ Neonatal HSV present in three forms SEM disease (Skin Eye and mucosal), CNS disease and Disseminated Disease.

\section{SEM disease}

$45 \%$ of cases of neonatal HSV present with mucocutaneous infection, which presents with only skin, eye, or mucosal findings - presenting as erythematous macules, which develop into vesiculopustules, crusts, or erosions. There are no evidence of systemic or central nervous system involvement. Neonatal mortality is rare and morbidity is minimal as well (only 5\% may develop neurologic abnormalities). ${ }^{?}$

\section{CNS disease}

This accounts for approximately $30 \%$ of cases of neonatal herpes. Neonate may present with lethargy, poor feeding, irritability, temperature instability or seizures. Diagnosis is made by brain MRI and Lumber puncture. CSF findings includes pleocytosis (defined as CSF WBC count $>25$ cells/ microliter in infants younger than 28 days old and $>10$ cells/microliter in patients aged 29-90 days; ${ }^{8}$ in conjunction with positive surface cultures and/or a finding of HSV DNA in the CSF. Sixty-eight percent of these neonates also have skin manifestation. Even with treatment, there is a $4 \%$ to $14 \%$ mortality rate and the majority of survivors will have long-term neurologic sequelae. ${ }^{7}$

\section{Disseminated disease}

The incidence of disseminated disease has decreased to approximately $25 \%$ of all neonatal herpes because of effective antiviral therapy. ${ }^{9}$ It usually presents around day 10 to 12 of life. Majority of infants with disseminated disease also have concurrent encephalitis. Disseminated disease involves multiple organs, including CNS, lungs, liver, adrenal, and SEM. Disseminated disease often starts with systemic symptoms which progress rapidly to jaundice, hypotension, respiratory failure, disseminated intravascular coagulation (DIC), and shock. Fifteen percent to $25 \%$ of survivors usually have neurologic sequelae. ${ }^{10}$ Maximum mortality is seen in disseminated disease which is usually caused by severe coagulopathy and extensive hepatic and pulmonary involvement. ${ }^{11}$

\section{Congenital HSV}

In utero (congenital) HSV transmission can occur with both primary and recurrent maternal HSV infections, with risk of congenital infection less in recurrent infections. The classical triad of clinical manifestations present at birth. ${ }^{11}$

i. Dermatological (active lesions, scarring, aplasia cutis, hyperpigmentation or hypopigmentation)

ii. Neurologic (microcephaly, intracranial calcifications, hydranencephaly)

iii. Ocular (chorioretinitis, microphthalmia, optic atrophy).

Isolation of HSV by culture remains the definitive method of diagnosing neonatal HSV infection. 12 CSF PCR is rapidly emerging tool with overall sensitivities of CSF PCR ranging from $75 \%$ to $100 \%$, with overall specificities ranging from $71 \%$ to $100 \%{ }^{12,13}$ The current recommendations are to treat all neonates with HSV disease parenteral with acyclovir given at $60 \mathrm{mg} / \mathrm{kg} / \mathrm{d}$ divided every 8 hours. ${ }^{14,15}$ Duration of treatment is 14 days for infants with SEM disease and 21 days for neonates with CNS and disseminated disease presentations. ${ }^{14}$ All neonates with CNS involvement should have their CSF PCR performed to report a negative PCR result and for normal CSF indices. ${ }^{12,16}$

\section{Lesson to clinicians:}

i. Refractory and recurrent neonatal seizures should alert the clinicians towards rare causes.

ii. Herpes infection in the newborn may present with recurrent seizures even in the absence of skin lesions and antecedent maternal history.

iii. CSF with lymphocytic predominance, acute infarcts especially in the temporal lobe and focal discharges on EEG should guide us to work up for Herpes encephalitis.

\section{Acknowledgments}

None.

\section{Conflicts of interest}

None.

\section{Funding}

None.

\section{References}

1. Brown ZA, Wald A, Morrow RA, et al. Effect of serologic status and caesarean delivery on transmission rates of herpes simplex virus from mother to infant. JAMA. 2003;289(2):203-209.

2. Whitley RJ, Kimberlin DW. Prophylaxis and treatment of herpes virus infections in children. Semin Pediatr Infect Dis. 1997;8(3):196-204.

3. Caviness AC, Demmler GJ, Almendarez Y, et al. The prevalence of neonatal herpes simplex virus infection compared with serious bacterial illness in hospitalized neonates. J Pediatr. 2008; 153(2):164-169.

4. Filippine MM, Katz BZ. Neonatal herpes simplex virus infection presenting with fever alone. J Hum Virol. 2001;4(4):223-225. 
5. Whitley RJ, Nahmias AJ, Visintine AM, et al. The natural history of herpes simplex virus infection of mother and newborn. Pediatrics. 1980;66(4):489-494.

6. Corey L, Whitley RJ, Stone EF, et al. Difference between herpes simplex virus type 1 and type 2 neonatal encephalitis in neurological outcome. Lancet. 1988;1(8575-8576):1-4.

7. Corey L, Wald A. Maternal and neonatal herpes simplex virus infections. N Engl J Med. 2009; 361(14):1376-1385.

8. Meehan WP, Bachur RG. Predictors of cerebrospinal fluid pleocytosis in febrile infants aged 0 to 90 days. Pediatr Emerg Care. 2008;24(5):287-293.

9. Whitley RJ, Corey L, Arvin A, et al. Changing presentation of herpes simplex virus infection in neonates. J Infect Dis. 1988;158(1):109-116.

10. Kimberlin DW, Lin CY, Jacobs RF, et al. Natural history of neonatal herpes simplex virus infections in the Acyclovir era. Pediatrics. 2001;108(2):223-229.

11. Kimberlin D. Herpes simplex virus, meningitis, and encephalitis in neonates. Herpes. 2004; 11(Suppl 2):65A-76A.
12. Troendle-Atkins J, Demmler GJ, Buffone GJ. Rapid diagnosis of herpes simplex virus encephalitis by using the polymerase chain reaction. $J$ Pediatr. 1993;123(3):376-380.

13. Kimura H, Futamura M, Kito H, et al. Detection of viral DNA in neonatal herpes simplex virus infections: frequent and prolonged presence in serum and cerebrospinal fluid. J Infect Dis. 1991; 164(2):289-293.

14. Pickering LK, Baker CJ, Kimberlin DW. Herpes Simplex. In: Pickering LK et al. (Eds.), Red book. Report of the Committee on Infectious Diseases. (29th edn), American Academy of Pediatrics, Elk Grove Village, Illinois, USA. 2012. p.398-408.

15. Kimberlin DW, Lin CY, Jacobs RF, et al. Safety and efficacy of highdose intravenous acyclovir in the management of neonatal herpes simplex virus infections. Pediatrics. 2001;108(2):230-238.

16. Kimberlin DW, Lakeman FD, Arvin AM, et al. Application of the polymerase chain reaction to the diagnosis and management of neonatal herpes simplex virus disease. National Institute of Allergy and Infectious Diseases Collaborative Antiviral Study Group. J Infect Dis. 1996;174(6):1162-1167. 